\title{
Evaluation of nutritional quality of commercially cultured Indian white shrimp Penaeus indicus
}

\author{
Hala Ali Abdel-Salam \\ Department of Zoology, Faculty of Science, Cairo University, Egypt
}

Email address:

Hala.ali2010@yahoo.com

To cite this article:

Hala A. Abdel-Salam. Evaluation of Nutritional Quality of Commercially Cultured Indian White Shrimp Penaeus indicus. International Journal of Nutrition and Food Sciences. Vol. 2, No. 4, 2013, pp. 160-166. doi: 10.11648/j.ijnfs.20130204.11

\begin{abstract}
Penaeus indicus is a valued crustacean species. Currently $P$. indicus is mainly cultured in many areas of the world to overcome the increase of population consumption. Yet, the biochemical composition of this species is still inadequately understood. So, the purpose of the present work was, therefore, to assess the protein, carbohydrates, lipid , vitamins $\mathrm{B}_{1}, \mathrm{~B}_{2}$, amino acids, minerals and protein electrophoresis to evaluate the nutritive quality of this cultured prawn. In the present study, nutritional analysis of muscle of both sexes indicated that the presence of a high amount of protein, 9 essential amino acids and 7 non-essential amino acid. Furthermore, the edible portion of females had the highest levels of vitamin $\mathrm{B}_{1}$ and $\mathrm{B}_{2}$ compared with their males. While, mineral contents of muscles of male indicate this decreasing arrangement $\mathrm{S}>\mathrm{P}>\mathrm{Ca}>\mathrm{Zn}>\mathrm{K}>\mathrm{Na}>\mathrm{Se}$ and females had this order $\mathrm{S}>\mathrm{P}>\mathrm{Zn}>\mathrm{Ca}>\mathrm{K}>\mathrm{Na}>\mathrm{Se}$. From the electrophoretic analysis of protein, 13 bands were identified around molecular weight 10.42 to121.07 KD, while the electrophoretic analysis of muscle of females showed 14 bands with molecular weight ranged from 10.09 to $198.7 \mathrm{KD}$. Regarding the results obtained in the present study in light of nutritional point of view commercial culture $P$. indicus is considered to be very good crustaceans species and can be very well used as food for human consumption .
\end{abstract}

Keywords: Penaeus Indicus, Proximate Composition, Amino Acids, Minerals, Protein Electrophoresis

\section{Introduction}

Edible crustaceans, such as crab, prawn, crayfish and lobster constitute one of the major sources of nutritious food for human being. There are much studies encouraging crustacean consumption [1-6]. The nutritive values of crustaceans depend upon their biochemical composition, such as protein, amino acids, lipid, fatty acids, carbohydrate, vitamins and minerals. Among seafood, shrimps contribute about $20 \%$ by volume of the world seafood market [7]. They have great importance in food consumed by human and other organisms. They are valuable in the diet, because apart from supply of good quality proteins and vitamins, they also contains several dietary mineral such as calcium, iron etc.., which are beneficial to human and other organisms; these minerals play an important role in maintaining the survival of organisms in a healthy and normal metabolism[6]. Therefore, shrimp is one of the most popular species as it is a part of almost every nation's traditional meal rich in protein and mineral.

The world's production of shrimp is about 6 million tones of which approximately 3.4 million tones are contributed by capture fisheries and 2.4 tones by aquaculture [8]. Aquaculture has been described as an underwater agriculture mainly to increase the production above the natural, wild level to overcome the increase of population consumption. Among the cultured shrimps, the Indian white shrimps, Penaeus indicus is one of the major commercial prawn species of the world. It prefers mud or sandy mud at depths of 2-90 meters. It has a life span of 18 months [8]. Currently P. indicus is mainly cultured in Saudi Arabia, Vietnam, Iran and India. Furthermore, Saudi Arabia was the largest producer in 2005 at nearly 11,300 tones [9].

The knowledge of the biochemical composition of any edible organism is extremely important since the nutritive value is reflected in biochemical contents [10]. However, information available on the chemical composition of shrimps species harvested from the aquacultures is very limited. [11, 12] Therefore, the objective of this study was to evaluate the proximate composition of basic biochemical constituents, such as total protein, lipids, carbohydrates, vitamins $\mathrm{B}_{1}, \mathrm{~B}_{2}$, amino acid composition, minerals $(\mathrm{Na}, \mathrm{K}$, $\mathrm{Zn}, \mathrm{Ca}, \mathrm{P}, \mathrm{S}$ and $\mathrm{Se}$ ) and protein electrophoresis of edible 
muscles of male and female P. indicus. The present study was planned to assess the evaluation the nutritive value through determination of biochemical compositions of edible muscles of male and female $\mathrm{P}$. indicus which commonly consumed by the local communities in Saudi Arabia and considered one of the common shrimps exported to Egypt. Moreover, to elucidate its real benefits and deal with a proposed management of the expanding populations of the aquaculture shrimps through its consumption as a cheap source of protein compared with natural wild shrimps.

\section{Material and Methods}

\subsection{Collection of Samples}

Cultured P. indicus samples of both sexes were collected from fisherman from Saudi Arabia. An attempt was made to collect consistent size ranges. Samples were put in crushed ice in insulated containers and brought to the laboratory for preservation prior to analysis. Shrimps were wrapped in aluminum foil and frozen

\subsection{Separation of Muscle away from Exoskeleton}

Fresh whole bodies of all samples of shrimps were stored at $-20^{\circ} \mathrm{C}$ to facilitate peeling process after thawing when needed as most crustaceans. After defrosting, the shrimps were separated into the exoskeleton (head and the outer body shell, i.e. shell) and the endoskeleton (i.e. edible muscles).

\subsection{Biochemical Analysis}

The muscle tissues samples were dried in an oven for 6 hours at $105^{\circ} \mathrm{C}$ and then burn in a muffle furnace for 16 hours at $550^{\circ} \mathrm{C}$ till reduced to ash [13] .

1. Powered samples of muscles were analyzed for total proteins by [14]. The total protein was estimated as per the Folin-Ciocalteu method with bovine serum albumin(BSA) as standard. $1 \mathrm{~g}$ of wet muscle tissue was homogenized in Homogenizer with $10 \mathrm{ml}$ of $0.1 \mathrm{M}$ Phosphate buffer. Take $1 \mathrm{ml}$ of tissue homogenate, $1 \mathrm{ml}$ of $0.1121 \mathrm{~N} \mathrm{NaOH}$ and keep it for 30 minutes, at room temperature, now add $8 \mathrm{ml}$ of distilled water and centrifuge at $4000 \mathrm{rpm}$ for 30 minutes. Take only $0.1 \mathrm{ml}$ supernatant and 123 add $0.9 \mathrm{ml}$ of distilled water to make volume $1 \mathrm{ml}$. Add $5 \mathrm{ml}$ of alkaline reagent ( $2 \mathrm{~g} \mathrm{Na} \mathrm{NO}_{2} 124$ in $0.1 \mathrm{~N} \mathrm{NaOH}: 4 \% \mathrm{Na}-\mathrm{K}$ tartarate 2\% CuSO4, 200:1:1) leave it for30 minutes at room 125 temperature. Add $0.5 \mathrm{ml}$ of Folin phenol reagent; leave it for 40 to 45 minutes 30 minutes at room 125 temperature. Add $0.5 \mathrm{ml}$ of Folin phenol reagent; leave it for 40 to 45 minutes at room 126 temperature. The color intensity was measured at $750 \mathrm{~nm}$ against reagent blank. Carbohydrates were determined by [15], $2 \mathrm{gm}$ of anthrone is dissovlved in 1 liter of $95 \% \mathrm{H}_{2} \mathrm{SO}_{4}, 4-5 \mathrm{ml}$ of the solution to be determined is measured into a test tube of $19-25 \mathrm{~mm}$ in diameter, and $8-10 \mathrm{ml}$ of the reagent added.
The solutions are at once thoroughly mixed by swirling, the color varies with the amount of carbohydrates.

Total lipids were analyzed by method of [16], $1 \mathrm{~g}$ each of the wet tissues of muscle from taken in clean dry test tubes were homogenized in $10 \mathrm{ml}$ chloroform :methanol mixture $(2: 1, \mathrm{v} / \mathrm{v})$ and centrifuged at $4000 \mathrm{rpm}$ for 20 minutes . After centrifugation, $0.5 \mathrm{ml}$ of supernatant containing the lipid was taken in a test tube and placed in boiling water for 10 minutes. Now keep the tube in cold water for 5 minutes in another test tube take $0.1 \mathrm{ml}$ of mixture from the cool test tube, add $5 \mathrm{ml}$ of Phospho-vanillin reagent and incubate reagent and incubate for 15 minutes at $37^{\circ} \mathrm{C}$. The absorbance was read at $540 \mathrm{~nm}$ against blank on spectrophotometer. All values were expressed on percentage dry weight basis.

2. Vitamin B contents: vitamin B1(Thiamin) ,B2 (Rioflavin) contents were analyzed using HPLC, the Varian 940-LC [17] .

3. Amino acids measured by high performance liquid chromatography (HPLC); Beckman 6300 amino acid analyzer [18], The profile of amino acids was done following high performance thin layer chromatographic (HPTLC), the muscles were dried ( $80 \mathrm{oC}$ for $3 \mathrm{hrs}$.), digested with $6 \mathrm{M}$ aqueous hydrochloric acid and dried under vacuum. The powdered sample was dissolved in distilled water and $5 \mu \mathrm{l}$ of sample was loaded on $8 \mathrm{~mm}$ thick pre-coated Silica gel The plate was developed in butane-Ammonia-Pyridine-Water (3.9:1:3.4:2.6) mobile phase. The plate was sprayed with ninhydrin reagent prepared in propan-2-ol and dried. The developed plate was documented using photo-documentation chamber (CAMAG-REPROSTAR 3) at UV $254 \mathrm{~nm}$ and UV366 nm lights, the plate was scanned at $500 \mathrm{~nm}$ The peak area of the sample was compared with standard amino-acids and quantified.

4. Mineral analysis: Analysis of 7 elements (Na, K, Zn, $\mathrm{Ca}, \mathrm{P}, \mathrm{S}$ and $\mathrm{Se}$ ) were measured using Perkin Elmer Atomic (800) with flow injection analysis system(FIAS). Each sample (2 g wet weight) was weighed. Twenty milliliters of concentrated nitric acid was added to each sample and the flask was left to stand overnight. Five milliliters of concentrated perchloric acid and $0.5 \mathrm{~mL}$ of concentrated sulfuric acid were added, and the flask was then heated until no white smoke was emitted. The samples were dissolved in $2 \%$ of hydrochloric acid and transferred into a volumetric flask, then analyzed using an atomic absorption spectrophotometer

5. Electrophoretic separation of proteins: Polyacrylamide gel electrophoresis (SDS-PAGE) electrophoresis was carried out using silver stain protocol [19]. Muscle samples $(3 \mathrm{~g})$ were homogenized with $27 \mathrm{~mL}$ of solubilizing agent $(2 \%$ SDS, $8 \mathrm{M}$ urea and $2 \% \beta$-mercaptoethanol), followed by heating at $85^{\circ} \mathrm{C}$ for $1 \mathrm{~h}$. Then the homogenate was centrifuged at $10,000 \mathrm{~g}$ for $15 \mathrm{~min}$ at room temperature [22]. The protein concentration of supernatant was obtained by the method of Lowry[23]. Protein patterns of different fractions were determined using sodium dodecylsulfate - 
polyacrylamide gel electrophoresis (SDS-PAGE), with115 $12 \%$ running gel and $4 \%$ stacking gel.

\subsection{Statistical Analysis}

The obtained data were used for descriptive statistical analysis consisting of means \pm standard deviation of five separated determinations. In addition, for comparing the different mean values, one-way ANOVA test were employed Means with the same letter for each parameters are not significantly different, otherwise they do $(\mathrm{P}<0.05)$. All the analyses were performed by using SPSS statistics, for Windows (Version 15.0).

\section{Results}

\subsection{Protein, Carbohydrates, Lipid Percentages and Vitamin B Analysis}

Table 1 shows the concentrations of total protein, carbohydrate, lipid, vitamins $\mathrm{B}_{1}$ (Thiamin) and $\mathrm{B}_{2}$ (Riboflavin) in edible muscles of male and female $P$. indicus. Protein was the major constituent in both sexes, while carbohydrates had the lowest percentage. The percentages of total protein, carbohydrate and lipid showed no significant differences between males and females. On the other hand, there were significant variations in the content of vitamin $B_{1}$ and $B_{2}$ between sexes, The edible portion of females had the highest levels of vitamin $B_{1}$ and $\mathrm{B}_{2}(0.316,0.418 \mathrm{mg} / 100 \mathrm{~g}$ respectively). Moreover, it was observed that the content of vitamin $B_{2}$ was higher in muscles of both sexes than vitamin $B_{1}$.

Table 1. Proximate composition of organic constituents and vitamins $B_{1}$ and $B_{2}$ in edible muscle tissues of male and female P. indicus

\begin{tabular}{|c|c|c|c|c|}
\hline \multicolumn{3}{|c|}{ Parameter } & \multicolumn{2}{|c|}{ Edible muscles } \\
\hline & Males & Females \\
\hline \multicolumn{3}{|c|}{ Carbohydrates (\%) } & $1.89 \pm 0.02^{\mathrm{a}}$ & $1.91 \pm 0.02^{\mathrm{a}}$ \\
\hline \multicolumn{3}{|c|}{ Protein $(\%)$} & $42.88 \pm 1.11^{\mathrm{a}}$ & $40.68 \pm 2.28^{a}$ \\
\hline \multicolumn{3}{|c|}{ Lipid (\%) } & $8.57 \pm 0.24^{\mathrm{a}}$ & $8.92 \pm 0.02^{\mathrm{a}}$ \\
\hline $\begin{array}{l}\text { Vitamin } \\
\text { protein) }\end{array}$ & $\mathrm{B}_{1}(\mathrm{mg} /$ & $100 \mathrm{~g}$ & $0.26 \pm 0.00^{b}$ & $0.32 \pm 0.00^{\mathrm{a}}$ \\
\hline $\begin{array}{l}\text { Vitamin } \\
\text { protein) }\end{array}$ & $\mathrm{B}_{2}(\mathrm{mg} /$ & $100 \mathrm{~g}$ & $0.32 \pm 0.00^{b}$ & $0.42 \pm 0.00^{\mathrm{a}}$ \\
\hline
\end{tabular}

Data are expressed as means \pm SD. of five separated determinations; means with the same letter for each parameters are not significantly different, otherwise they do $(\mathrm{P}<0.05)$.

\subsection{Amino Acids Analysis}

The results obtained from this study indicated the presence of 9 essential amino acids (arginine, histidine, lysine, threonine, methionine, leucine, isoleucine, valine and phenylalanine) (Table 2). The highest average concentrations of arginine were recorded in edible muscles of male and female $(4.28,4.97 \mathrm{mg} / 100 \mathrm{~g}$ respectively) compared to other essential amino acids. On the other hand, methionine $(1.28 \mathrm{mg} / 100 \mathrm{~g})$ and histidine $(1.30 \mathrm{mg} / 100 \mathrm{~g})$ were found in low level in males and females respectively. Furthermore, the recorded data showed that, females had lower contents of all essential amino acid contents than males except arginine and methionine where significant increase was recorded.

Table 2. Essential amino acids analysis edible muscle of male and female P. indicus.

\begin{tabular}{lcc}
\hline Essential amino acids (mg/ 100g) & Males & Females \\
\hline Arginine & $4.28 \pm 0.02^{\mathrm{b}}$ & $4.97 \pm 0.03^{\mathrm{a}}$ \\
Histidine & $1.39 \pm 0.02^{\mathrm{a}}$ & $1.30 \pm 0.00^{\mathrm{b}}$ \\
Lysine & $1.50 \pm 0.02^{\mathrm{a}}$ & $1.34 \pm 0.02^{\mathrm{b}}$ \\
Threonine & $1.75 \pm 0.02^{\mathrm{a}}$ & $1.48 \pm 0.03^{\mathrm{b}}$ \\
Methionine & $1.28 \pm 0.02^{\mathrm{b}}$ & $1.46 \pm 0.02^{\mathrm{a}}$ \\
Leucine & $2.57 \pm 0.02^{\mathrm{a}}$ & $2.52 \pm 0.02^{\mathrm{a}}$ \\
Isoleucine & $1.77 \pm 0.03^{\mathrm{a}}$ & $1.50 \pm 0.02^{\mathrm{b}}$ \\
Valine & $2.30 \pm 0.02^{\mathrm{a}}$ & $1.97 \pm 0.02^{\mathrm{b}}$ \\
Phenyl alanine & $2.58 \pm 0.03^{\mathrm{a}}$ & $2.26 \pm 0.02^{\mathrm{b}}$ \\
\hline
\end{tabular}

Data are expressed as means \pm SD. of five separated determinations; means with the same letter for each parameters are not significantly different, otherwise they do $(\mathrm{P}<0.05)$.

Table 3. Non-essential amino acids analysis edible muscle of male and female P. indicus

\begin{tabular}{lcc}
\hline Non-essential amino acids ( mg/ 100g) & Males & Females \\
\hline Proline & $2.97 \pm 0.07^{\mathrm{a}}$ & $2.81 \pm 0.05^{\mathrm{b}}$ \\
Tyrosine & $2.09 \pm 0.07^{\mathrm{b}}$ & $2.44 \pm 0.00^{\mathrm{a}}$ \\
Glycine & $2.52 \pm 0.07^{\mathrm{b}}$ & $2.73 \pm 0.07^{\mathrm{a}}$ \\
Alanine & $1.94 \pm 0.05^{\mathrm{a}}$ & $1.68 \pm 0.05^{\mathrm{b}}$ \\
Serine & $2.19 \pm 0.07^{\mathrm{b}}$ & $2.28 \pm 0.05^{\mathrm{a}}$ \\
Glutamic acid & $5.42 \pm 0.05^{\mathrm{b}}$ & $4.71 \pm 0.05^{\mathrm{a}}$ \\
Aspartic acid & $4.45 \pm 0.05^{\mathrm{a}}$ & $4.17 \pm 0.36^{\mathrm{b}}$ \\
\hline
\end{tabular}

Data are expressed as means \pm SD. of five separated determinations; means with the same letter for each parameters are not significantly different, otherwise they do $(\mathrm{P}<0.05)$.

Table 4. Mineral analysis of edible muscle of male and female P. indicus

\begin{tabular}{lcc}
\hline \multirow{2}{*}{ Parameter (mg/ 100g dry weight) } & \multicolumn{2}{c}{ Edible muscles } \\
& Males & Females \\
\hline $\mathrm{Na}$ & $31.65 \pm 1.97^{\mathrm{a}}$ & $29.68 \pm 0.36^{\mathrm{b}}$ \\
$\mathrm{K}$ & $33.27 \pm 0.96^{\mathrm{a}}$ & $29.89 \pm 0.27^{\mathrm{a}}$ \\
$\mathrm{Zn}$ & $40.62 \pm 8.78^{\mathrm{b}}$ & $43.17 \pm 1.52^{\mathrm{a}}$ \\
$\mathrm{Ca}$ & $45.09 \pm 1.30^{\mathrm{a}}$ & $39.96 \pm 2.20^{\mathrm{a}}$ \\
$\mathrm{P}$ & $74.32 \pm 1.99^{\mathrm{a}}$ & $75.45 \pm 1.78^{\mathrm{a}}$ \\
$\mathrm{S}$ & $85.43 \pm 3.25^{\mathrm{b}}$ & $102.47 \pm 2.80^{\mathrm{a}}$ \\
$\mathrm{Se}$ & $0.02 \pm 0.00^{\mathrm{a}}$ & $0.03 \pm 0.00^{\mathrm{a}}$ \\
\hline
\end{tabular}

Data are expressed as means \pm SD. of five separated determinations; means with the same letter for each parameters are not significantly different, otherwise they do $(\mathrm{P}<0.05)$.

As shown in Table 3, the edible portion of both sexes of P. indicus accumulated 7 non-essential amino acids (Proline, tyrosine, glycine, alanine, serine, glutamic acid and aspartic acid). Glutamic acid $(5.42,4.7 \mathrm{mg} / 100 \mathrm{~g})$ and aspartic acid $(4.45,4.17 \mathrm{mg} / 100 \mathrm{~g})$ had the highest concentration in muscles of male and female respectively. While alanine $(1.94,1.68 \mathrm{mg} / 100 \mathrm{~g}$ in males and females respectively) had the lowest level compared to other non-essential amino acids. In general, males showed significant increase of proline, alanine and aspartic acid contents in comparison with those of females, which had the highest concentrations of tyrosine, glycine, serine and glutamic acid in their edible muscles. 


\subsection{Mineral Analysis}

The results of the mineral analysis are recorded in Table 4. The data showed that, S content was very high in edible muscles of both sexes compared to other metals, while Se had the lowest concentrations. Males displayed the maximum contents for $\mathrm{Na}, \mathrm{K}$ and $\mathrm{Ca}$ (31.65, 33.27, 45.09 $\mathrm{mg} / 100 \mathrm{~g}$ respectively). On the other hand, they had the lower level of S, Zn and Se (85.43, 40.62, $0.022 \mathrm{mg} / 100 \mathrm{~g}$ respectively) compared to their females and $\mathrm{P}$ concentration had nearly the same mean value in both sexes, where non-significant variation was recorded between sexes.

\subsection{SDS-gel Electrophoresis}

Obviously, considerable variations in the SDS-gel electrophoresis of muscle proteins fractionation between males and females were detected (Photo 1 \&Table 5). For protein fraction of males, 13 bands were identified around molecular weight 10.42 to $121.07 \mathrm{KD}$, while the electrophoretic analysis of muscle of females showed 14 bands with molecular weight ranged from 10.09 to 198.7 KD.

\section{Disscussion}

The recorded data of the present study indicated that no significant differences were observed in muscles protein, carbohydrate and lipid contents between males and females. Protein was found as the major constituent in the muscle of both sexes. This result agreed with other studies which stated that protein is the most prominent biochemical component of crustaceans [10, 20-24]. One of the major requirements of prawn culture is the transformation of dietary protein into tissue protein. Protein is essential for normal function, growth and maintenance of body tissues. Its content is considered to be an important tool for the evaluation of physiological standards [7]. The high protein level in edible muscles of $P$ indicus in the present study indicates their high nutritive value. . The high protein content in crustaceans species can be attributed to its omnivorous feeding habit [25] and also may be due to the fact that it is the main component of the contractile elements of the striated muscles [26 ]. According to [27] the protein level in $P$. indicus was varied from 44.62 to $80.87 \%$. The mean values of protein in the present study were slightly lower than that in marine shrimps $P$. semisulctus and P. japonicus from the Suez Gulf [28], and than river prawn Macrobrachium vollenhovenii as reported by [10]. Additionally, the protein contents were lower than that in edible muscles of mantis shrimps E. massavensis which collected from the Egyptian Mediterranean, coast off Port Said [21] and that of males E. massavensis from Ismailia and Suez regions [24]. On the other hand, the recorded protein percentage showed an increase compared to Metapenaeus stebbingi, M. monoceros [21], females E. massavensis [24] and crab species Portunus pelagicus [21].

The obtained data showed that the concentration of carbohydrates in the muscle of female $P$. indicus showed non-significant increase compared to their males. This is not in agreement with the studies of [29-31] which obtained that the edible muscles males of marine prawns shown significantly higher carbohydrate values than in females. Moreover, the recorded values of carbohydrates in the present result were less than in muscles of crustaceans species [10, 21, 24].

Lipids displayed more or less similar percentages in muscles of both sexes of $P$. indicus. While, these recorded values were lower than in edible muscles of crustances species [10, 21, 21-24, 28]. According to [32] lipids are highly efficient as sources of energy and they contain twice the energy of carbohydrates and proteins. As a general rule, they act as major food reserve along with protein and are subject to periodic fluctuations influenced by environmental variables like temperature. [33].

Regarding vitamins, no extensive studies have been published on the vitamin contents in the muscle of various species of marine invertebrates. The present study revealed that, edible muscles of females had higher vitamin B1 (Thamin) and B2 (Riboflavin) contents than males. The wide variability of vitamin contents among males and females could be attributed to sex variation as previously reported by [34]. Furthermore, the high level of vitamin $B_{1}$ and $\mathrm{B}_{2}$ in edible muscles of $P$. indicus indicates its high nutritive value.

Amino acids are the building blocks of proteins and serve as body builders. They are utilized to form various cell structures, of which they are key components and they serve as source of energy [7]. The recorded data in the present study indicate the presence of 9 essential amino acids (arginine, histidine, lysine, threonine, methionine, leucine, isoleucine, valine and phenylalanine) and 7 non-essential amino acids (proline, tyrosine, glycine, alanine, serine, glutamic acid and aspartic acid). In aquaculture prawn Macrobrachium rosenbergii, nineteen amino acids were detected, among these eleven are essential and, eight are non-essential amino acids [7], while nine essential amino acids and nine non-essential were detected by [35] in edible muscles of Procambarus clarkii and Erugosquilla massavensis. The different amino acids in flesh of crustaceans species might be associated with the varying tastes as well as textural properties of meat of the crustaceans species [10]. Previously, in this respect, according to [36] glycine, alanine, serine and threonine give tasty sweet, while arginine, leucine, valine, methionine, phenylalanine and histidine give bitter taste. In the present study, the levels of arginine, glutamic acid and aspartic acid were high in respect to the other amino acids in edible muscles of both sexes. Furthermore, amino acids show considerable variation in proportions from male to females. To be precise, males tended to have high essential amino acid contents in muscles than the females. This suggests sex differences and physiology differences of adult female prawns. The recorded data indicate that nutritionally the adult male prawns were good or even better than the adult 


\section{Conclusion}

In the present work, nutritional analysis of muscle of both sexes of $P$. indicus indicate the presence of high amount of protein, low level of carbohydrates, moderate content of lipids, considerable amount of vitamins $\mathrm{B}_{1}$ and $\mathrm{B}_{2}$, nine essential amino acids and seven non-essential amino acids which have benefit for man. In addition to $P$. indicus form a good source of minerals where seven important minerals; $\mathrm{Na}, \mathrm{K}, \mathrm{Zn}, \mathrm{Ca}, \mathrm{P}, \mathrm{S}$ and $\mathrm{Se}$ are recorded that serve a variety of functions for man. Therefore, the muscles of both sexes of this species of crustaceans are ranked as protein and mineral rich edible crustaceans. Furthermore, from the present electrophoretic protein analysis of muscles of males and females, the recorded data detect 13 protein bands in males and 14 protein bands in females. The differences in chemical compositions and nutritional quality between males and females might be associated with the characteristics of shrimp.

\section{Acknowledgements}

This paper is part of our research work on crustaceans species funded by the Deanship of Scientific Research, Majmaah University, Saudi Arabia. The financial support, continuous help and fruitful cooperation provided by are gratefully acknowledged.

\section{References}

[1] J. Oehlenschläger, Marine fish - $\mathrm{a}$ source for essential elements? In: Luten, J.B., T. Borresen, and J. Oehlenschla"ger (Eds.). "Seafood from producer to consumer, integrated approach to quality, 38. Elsevier Science B.V., Amsterdam, Netherlands. Pp. 641-652, 1997.

[2] S.H. Bügel, B. Sandström, and E.H. Larsen, "Absorption and retention of selenium from shrimps in man,". J. Trace Elem. Med. Biol., 14: 198-204, 2001.

[3] A., M Küçükgülmez, Y. Çelik, Yanar, B. Ersoy, and M. Çikrikçi. , "Proximate composition and mineral contents of the blue crab (Callinectes sapidus) breast meat, claw meat and hepatopancreas," J. Food Sci. Technol., 41: 1023-1026, 2006.

[4] S., A. Barrento Marques, B. Teixeira, P. Vaz-Pires, M.L., Carvalho and M.L. Nunes, "Essential elements and contaminants in edible tissues of European and American lobsters," Food Chemistry, 111(4): 862-867, . 2008.

[5] Y. Wardiatno, J Santoso, and A Mashar,.. "Biochemical Composition in Two Populations of the Mantis Shrimp, Harpiosquilla raphidea (Fabricius 1798) (Stomatopoda, Crustacea. Maret, 17 (1) 49-58, 2012.

[6] Y. Wardiatno, and A Mashar. , "Biological information on the mantis shrimp, Harpiosquilla raphidea (Fabricius 1798) (Stomatopoda, Crustacea) in Indonesia with highlight of its reproductive a aspects,'J. Tropical Biol. Conserv., 7: 65-71, 2010.
[7] S. Bhavan, Saravana,,S, Radhakrishnan,S., Shanthi, R.and Poongodi, R., "Proximate composition and profiles of amino acids and fatty Acids in the muscle of adult males and females of commercially viable prawn species Macrobrachium rosenbergii collected from natural culture environments", Inter. J. Biolog., 2( 2) :107-119, 2010

[8] Kumulu, M., "Larval growth and survival of Penaeus indicus (Decapoda: Penaidae) on live feeds" Turkish J. Biolog. 22: 235-245, 1998.

[9] T.W. Flegel, , "Detection of major penaeid shrimp viruses in Asia, a historical perspective with emphasis on Thailand. Aquaculture, 258:1-33, 2006.

[10] F.A.R. Ehigiator and E.A. Oterai , "Chemical composition and amino acid profile of a caridean prawns (Macrobra chium vollenhoveanil ) from Ovia river and tropical periwinkle (Tympanonus fusctus) from Benin river" , Edo state, Nigeria. IJRRAS 11 (1) :162-167, 2012.

[11] S. Ravichandran, , G. Rameshkumar, and A Rosario Prince,., "Biochemical Composition of Shell and Flesh of the Indian White Shrimp Penaeus indicus (H.milne Edwards 1837). Americ. Eurasian J. Sci. . Res.4 (3): 191-194. 2009.

[12] L., Laxmillatha and Laxminarayana, "Haemolymph proteins of the Indian white shrimp, Penaeus indicus (H. Milne Edwards), ”Indian J. Fish., 50(3) : 279-290,2003.

[13] V.D. Sidwell, B.R Stillings, and G.M. Knobl, The fish protein concentrations.10- Nutrition quality and use in foods ," J. Food Technol., 14(8): 40-46,1970.

[14] Lawery,., W.H Daughaday, N.J Rosebroughady, and Field, W.S, " Determination of cerebral protein using Folin phenol reagent, ” J. lab. Clin Med.,39: 663-665,1952.

[15] B.J. Barber, N. J. Blanke, (1981). "Energy storage and utilization in relation to gametogenesis in Astropecten irradians concntricus," Exp. Mar. Biol. Ecol.,52:1211-134.

[16] D.L. Holland and P.J. Hannant, "Addendum to a micro analytical scheme for the biochemical analysis of marine invertebrate larvae, J. Mar. Biol. Ass. U.K., 51:659-668, 1973.

[17] G. Brubacher, W Muller Mulot, D Southgate, Methods for determination of vitamins in food," Elsevier Applied Science Publishers, London and New York, p.166, 1985.

[18] MD Gaithersburg, Official methods of analysis of aoac international, aoac international, USA, official method pp.982.930, (Modified). 17th Ed., 2000.

[19] UK Laemmli, "Cleavage of structural proteins during the assembly of the head of bacteriophage T4, " Nature, 227: 680-685,1970.

[20] R. ROSA, and M.L. Nunes,: "Biochemical changes in different tissues of the mantis shrimp, Oratoasquilla nepa (stomatopoda) during reproductive cycle, "Ind. J. Mar. Sci., 247-249, 2002.

[21] W.S Sallam, T. A. Temraz, and H. R Gabar, "Biochemical compositions and heavy metals accumulation in some commercial crustaceans from the Mediterranean coast off Port Said", Egypt., J. Egypt. Ger. Soc. Zool. 51 D: 127-141, 2006.

[22] P. Sriket, S Benjakul, W .Visessanguan, and Kijroongrojana, 
K. , Comparative studies on 476 "chemical composition and thermal properties of black tiger shrimp (Penaeus monodon) 477 and white shrimp (Penaeus vannamei) meats", Food Chem.103:1199-1207, 2007.

[23] G.K Dinakaran, P. Soundarapandan,.and S.K Chandra , "Proximate analysis of edible Palaeomonid prawn, Macrobrachium idea, ” J. Biological Sciences. 1(3): 78-82, 2009.

[24] H.A. Abdel-Salam and A.H. S Hamdi, "Biochemical compositions and heavy metals accumulation capacity of the marine mantis shrimp Erugosquilla massavensis from the Suez canal(El- Suez and Ismailia) Egypt. ,” J. Egypt. Germ. Soc. Zoo.,61, 2011.

[25] Bello-Olusoji,. A.M. Balogun, O.A. Fagbenro, and N. Ugbaja, "Food and feeding studies of the African river prawn. In: Proceedings of Fish and Shellfish Larviculture Symposium. Lavens P., Japan E. and Roelants, I. (Eds.). Europ. Aquac. Soc., Special Publication. 24: 425-427, 1995.

[26] H.M. Mona, S.N Geasa, M.K. Sharshar, and M. E. Morsy , "Chemical composition of freshwater crayfish Erugosquilla massavensis and its nutritive values, ”. Egypt,. J. aquat. Biol. And fish., 4(1):19-34,2000.

[27] C. Sambhu, and V. Jayaprakas, "Effect of hormones on growth, Food conversion and proximate (Milne Edwards)," Indian J. Mar. Sci., 23: 232-235, 1994.

[28] S.A Hamdi, and K. H. Zaghloul, "Evaluation of the crawfish Procambarus clarkli as a cheaper source of human diet in comparison with two marine shrimps in Egypt., J. Egypt. Ger. Soc. Zool. 50 D: 153-174, 2006.

[29] K.M. Ajith, , Studies on the proximate composition of the prawn Macrobrachium idella (Hilgendorf). M. Phil Thesis, Annamalai University, 1990.

[30] A.K. Tiwary, "Nutritional status of edible palaemonid Wardiatno, Y. \& Mashar. "Biological information on the mantis shrimp, Harpiosquilla raphidea (Fabricius 1798) (Stomatopoda, Crustacea) in Indonesia with a highlight of its reproductive aspects, " J. Tropical Biol. Conserv., 7: 65-71, 2009.
[31] S.K. Chandra, Proximate composition of edible palaemonid prawn Macrobrachium idae M.Sc. Thesis, Annamalai Universit, Heller, 1862, 2009.

[32] M Okuzumi, and T. Fujii, Nutritional and functional properties of squid and cuttlefish. National Cooperative Association of Squid Processors, California. Pp 223, 2000.

[33] R. Nagabhushanam, and U.M.Farooqui, "Mobilization of protein, glycogen and lipid during 429 ovarian maturation in marine crab, Scylla serrata Forsskal, ”Indian J. Mar. Sci. 11: 184- 186, 2000.

[34] M.,G. Das, M Sanchez. H Bsrtolo,. and H Oliveira , "Vitamin content of fish and fish products consumed in Portugal, ”. J. Fish . Res. Bd. Canda, 26:2960-2974,2003.

[35] S. A. Hamdi, "Muscle and exoskeleton extracts analysis of both fresh and marine crustaceans P. clarki \& E massavensis", African J. Pharm.Pharmacolo. 5(13):1589-1597, 2011.

[36] Z.E Sikorski, A Kolakkowska,.and B.S Pan, The nutritive composition of the major groups of marine food organisms. In: Sikorski, Z.E (Eds). Seafood Resources, Nutritional composition and preservation.CRC. Press Florida, Pp 29-54, 1990.

[37] F.O, Abulude., L.O Lawal, G., Ehikhamen, W.O., Adesanya, and S.L. Ashafa, "Chemical composition and functional properties of some prawns from the coastal area of Ondo state, Nigeria, ". Electron. J. Agric. Food Chem., 5, $1235-1240$

[38] E. Penas, "Se improves indole glucosinolate hydrolysis products content, Se-methylselenocysteine content ,of antioxidant capacity and potential anti-inflammatory properties of sauerkraut, " Food Chemistry, 132(2): 907-914, 2012.

[39] E. Roy, Martin, J. George Flick, , J. Wiley and Sons, , Composition of the Edible Portion of Raw (Fresh or Frozen) Crustaceans, Finfish, and Mollusks. II Macroelements: Sodium, Potassium, Chlorine Calcium, Phosphorus, and Magnesium. Species, Products, Processing, and Safety. ISBN: 1118229533, 9781118229538, 2012. 